\begin{tabular}{|c|c|c|c|c|c|c|}
\hline \multirow{4}{*}{ Impact Factor: } & ISRA (India) & $=3.117$ & SIS (USA) & $=0.912$ & ICV (Poland) & $=6.630$ \\
\hline & ISI (Dubai, UAE & $=0.829$ & РИНЦ (Russia) & $=0.156$ & PIF (India) & $=1.940$ \\
\hline & GIF (Australia) & $=0.564$ & ESJI (KZ) & $=8.716$ & IBI (India) & $=4.260$ \\
\hline & JIF & $=1.500$ & S.IIF (Moroce & $=5.667$ & OAJI (USA) & $=0.350$ \\
\hline
\end{tabular}

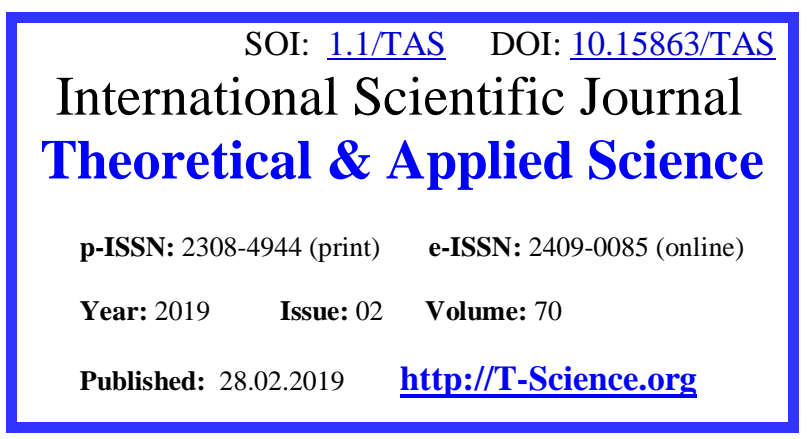

SECTION 7. Mechanics and mechanical engineering.
QR - Issue

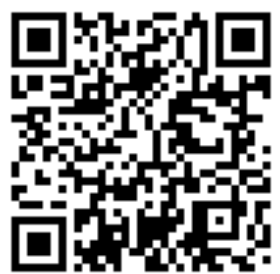

Stanislav Vladislavovich Antimonov associate Professor, faculty of applied biotechnology and engineering Orenburg State University sergeigray@gmail.com

Alexander Viktorovich Kolotvin head of the Department, faculty of applied biotechnology and engineering Orenburg State University mahpp@mail.osu.ru

\title{
TECHNOLOGICAL LINE OF RECYCLING OF MATERIAL RESOURCES OF AGRO-INDUSTRIAL COMPLEXES OF THE ORENBURG REGION
}

\begin{abstract}
Currently, high attention is paid to the problem of reducing the energy intensity of the process of grinding grain raw materials and secondary material resources, while improving the quality of the product, leading to an increase in economic efficiency in feed production of the Russian Federation [1].

Currently, in the production of combined feed, extrusion technologies are used proactively, which include such processes as: pressing, mixing and grinding. This technology is associated with high energy and raw materials costs.

It should be noted that the optimal technology of processing of secondary material resources, for example, such as husks (a product of processing of cereals) should ensure the preservation of the useful properties of raw materials at each stage of its processing, in particular at the stages of its extrusion and grinding.

This topic is dedicated to the work of such scientists as: L. R., F. Kika, Korotkov V. G., Antimonov S. V., Kobylkin D. V., Kholodilin, V. P., O. Y. Sokolov, N. V. Zaitsev, S. I., Zurabyan, Nekhoroshev M. V., Fedorenko S. I., Zurabyan, V. M. and V. I. Skrebtsov, and A. Y. Stavissky, D. J. Bryce, G. W. Parks, A. E. Lipska, W. J. Parker, R. M. Estevc, M. H. Gollis, R. Garcia, and others, they addressed the creation of a mathematical apparatus and design of grinders of various types, including the grain size under the conditions of vacuum, high pressure, low and high temperature conditions, etc.

One of the above problems is to optimize the process of grinding of secondary material resources by using as a positive factor of negative temperatures - cryogenic.

It is established that the research was conducted dedicated to the problem of influence of low temperatures on the resistance of the grain to be ground. It was found that if the grain temperature is negative (below $-50 C$ and below), the free and bound moisture, always located in the pores, capillaries and intercellular spaces of the grain, turning into ice and expanding, loosens the grain structure and weakens the bonds between its constituent parts. As a result, the resistance of the secondary material resources in the grinding process is significantly reduced. In addition, the decrease in temperature leads to a decrease in the kinetic energy of the translational motion of the molecules of the substance, reduces their speed and free path length, the grain becomes less viscous and plastic, its fragility increases [2].

Thus, it is possible to create a fundamental basis and practical recommendations for the implementation of the process of cryogenic secondary material resources for the purpose of turning into a feed product for farm animals. Analogues of the technology is not available in Russia not abroad.

Key words: crushing, power consumption, grain raw materials, technological process, power, formula-feed industry, mathematical model, resource-saving.
\end{abstract}

Language: English 


\begin{tabular}{|c|c|c|c|c|c|c|}
\hline \multirow{4}{*}{ Impact Factor: } & ISRA (India) & $=3.117$ & SIS (USA) & $=0.912$ & ICV (Poland) & $=6.630$ \\
\hline & ISI (Dubai, UAE & $=0.829$ & РИНЦ (Russia & $=0.156$ & PIF (India) & $=1.940$ \\
\hline & GIF (Australia) & $=0.564$ & ESJI (KZ) & $=8.716$ & IBI (India) & $=4.260$ \\
\hline & JIF & $=1.500$ & SJIF (Morocco & $=5.667$ & OAJI (USA) & $=0.350$ \\
\hline
\end{tabular}

Citation: Antimonov, S. V., \& Kolotvin, A. V. (2019). Technological line of recycling of material resources of agro-industrial complexes of the Orenburg region. ISJ Theoretical \& Applied Science, 02 (70), 258-261.

Soi: http://s-o-i.org/1.1/TAS-02-70-23 Doi: rostef https://dx.doi.org/10.15863/TAS.2019.02.70.23

\section{Introduction}

Cryogenic processing of secondary material resources before and in the implementation process of degeneration will preserve the biological valuable substances in the processed material, such as lignin, cellulose, to prevent the formation of undesirable substances such as melanoidins and many other substances harmful to the health of animals and as a consequence for a person's characteristic [3].

It should also be noted that researchers in the field of optimization of technologies of extrusion processing of grain raw materials and secondary material resources, for example, Khanin V. P., Polishchuk V. Yu., also did not apply cryotherapy on extruded raw materials.

In this regard, it is important to conduct research on the development of technology for processing secondary material resources of agroindustrial complexes of the Orenburg region with the use of both extrusion and cryogenic technologies.

The object of the study is the secondary material resources of agro-industrial complexes of the Orenburg region.

Purpose: development of energy and resourcesaving technology for the production of feed and feed additives using cryogenic technologies for waste agro-industrial complex of the Orenburg region [4].

Scientific novelty includes the development of technology for obtaining high-quality feed and feed additives by increasing their homogeneity and preventing the destruction of the cellulose-legnin complex, as well as reducing the specific energy costs in the process of their production based on cryotherapy on the processed material. An important issue for the consumer is the economic efficiency of the implemented technology.

In the proposed technology, the reduction of energy consumption is possible due to:

- optimization of the grinding process of raw materials by selecting the optimal device for grinding frozen raw materials;

- applications of processing of crushed raw materials with chemical reagents;

- applications of grinding at low air pressure;

- extrusion treatment of the prepared mixture.

To optimize the grinding operation in the line for the production of feed and feed additives, we conducted comparative tests of several types of small-capacity grinding machines, which are produced by Russian enterprises [5].

The main criteria for evaluating their effectiveness are their versatility and the ability to adapt to different technological schemes, working on both traditional and non-traditional raw materials.

The decisive factor in assessing the efficiency of the grinding device was its mobility in terms of changes in the technological process, for example, in the transition from one type of vegetable raw material to another or reconfiguration of its technological parameters.

The comparative analysis of qualitative and quantitative indicators of work of the grinders presented in the market of Russia of the grinding machines of a certain type and class (table 1) which revealed at their work the following regularities and a number of the essential shortcomings essentially limiting application of these grinders in forage preparation was carried out $[6,7]$.

Table 1-Comparative analysis of qualitative and quantitative indicators of the shredders presented on the Russian market (for example, the device of three types).

\begin{tabular}{|c|c|c|c|c|}
\hline Grinding machine & $\begin{array}{c}\text { Rotation } \\
\text { frequency of } \\
\text { working bodies }\end{array}$ & Gap & The restructuring of the modes by replacing \\
\cline { 3 - 5 } Knife («Farmer») & fixed & absents & not provided & not provided \\
\hline $\begin{array}{c}\text { Hammer mill (JSC } \\
\text { «Valley») }\end{array}$ & fixed & fixed & not provided & not provided \\
\hline $\begin{array}{c}\text { Cone (based on the } \\
\text { mill MTM «Zenit») }\end{array}$ & fixed & regulates & absents & $\begin{array}{c}\text { replacement set of } \\
\text { working bodies }\end{array}$ \\
\hline
\end{tabular}




\begin{tabular}{|c|c|c|c|c|c|c|}
\hline \multirow{4}{*}{ Impact Factor: } & ISRA (India) & $=3.117$ & SIS (USA) & $=0.912$ & ICV (Poland) & $=6.630$ \\
\hline & ISI (Dubai, UAE & $=0.829$ & РИНЦ (Russia & $=0.156$ & PIF (India) & $=1.940$ \\
\hline & GIF (Australia) & $=0.564$ & ESJI (KZ) & $=8.716$ & IBI (India) & $=4.260$ \\
\hline & JIF & $=1.500$ & SJIF (Morocco & $=5.667$ & OAJI (USA) & $=0.350$ \\
\hline
\end{tabular}

Based on the analysis of table 1 conclusions about the universality of the shredders, which are presented in the form of table 2, based on the possibility of controlling the grinding process in the grinding machines considered by the structural or physical and chemical properties of the crushed raw materials.

Further analysis of the work of the above grinders was carried out on the basis of experimental studies [8].

The object of study for the study of the crushers and subsequent analysis, as the crushed raw materials were selected the following crops, which are the most common components of most feed formulations: wheat varieties "Saratov 29" with an initial moisture content of $6.3 \%$ and moistened to a moisture content of $15 \%$ and barley varieties "Vinner" with an initial moisture content of $6.3 \%$ and moistened to a humidity of $15 \%$. In addition, the production waste was crushed: buckwheat and sunflower husk with an initial moisture content of $6.3 \%$ and moistened to a moisture content of $15 \%$ [9].

The sample of raw materials of a given mass was crushed in all three types of crushers. Fractional composition of the crushed product was analyzed according to GOST13496.9-96.

After substantiation and final selection of the most optimal design of the shredder, it was decided to extrude mixtures prepared as follows: $80 \%$ of wheat bran $+20 \%$ of sunflower husk treated with $\mathrm{Na}_{2} \mathrm{CO}_{3}$ solution with a concentration of 3,4 and $5 \%$ and moistened, respectively, to 18,20 and $22 \%$.

Studies have found that, for example, the rotary grinder " Farmer "(manufacturer "Uralspetsmash") regardless of the type of raw material and its physical and chemical properties (culture, humidity) shows a stable size of the resulting crushed product in the range of 1.4-1.9 mm, which corresponds to only one group of size, which can be fed only one type of farm animals - cattle, and for fattening pigs or poultry grain of such size will no longer meet the zootechnical requirements for crushed grain, which makes the widespread use of this grinder problematic. It should be noted that the size of the resulting product obtained on the shredder type "Farmer" practically does not affect the hardness of the milled culture [10].

Analysis of the results showed that when extruding mixtures consisting of $80 \%$ wheat bran + $20 \%$ sunflower husks treated with a solution of 3,4 and $5 \% \mathrm{Na}_{2} \mathrm{CO}_{3}$ with moisture $\mathrm{W}=18,20$ and $22 \%$ for extrusion, it is best to use the original mixture secondary crushed on a rotary crusher treated with a solution of $4 \% \mathrm{Na}_{2} \mathrm{CO}_{3}$ with moisture $\mathrm{W}=22 \%$ at $\mathrm{n}=105 \mathrm{rpm}$ of the extruder screw.

The results of experimental studies of the process of grinding sunflower husks with a moisture content of $15 \%$ when comparing the performance and energy intensity at different temperatures (at a temperature of $20{ }^{\circ} \mathrm{C}$ and $-120{ }^{\circ} \mathrm{C}$ ) for different designs of grinders showed that the greatest reduction in specific energy consumption occurs in the rotor crusher.

\section{Conclusion}

As shown by the results of studies on the optimization of the grinding process of grain and ligninocellulosic raw materials by selecting the optimal device for grinding frozen raw materials is most effective in terms of energy consumption, grinding is carried out on a rotary crusher (the design of LLC "Uralspetsmash"), as with almost the same performance, the rotary crusher is less energyintensive.

The proposed design of the crusher allows to obtain a crushed product of higher quality that meets the requirements of GOST.

In the production line of extruded feed for extrusion it is best to use the original mixture is secondary milled on a rotary crusher, treated with a solution of $4 \% \mathrm{Na}_{2} \mathrm{CO}_{3}$ with a moisture $\mathrm{W}=22 \%$ at $\mathrm{n}=105 \mathrm{rpm}$ of the extruder screw.

References:

1. Agote, I. (2011). Rheological study of waste porcelain feedstocks for injection moulding / Agote I.,Odriozola A., Gutierrez M., Santamari a A., Quintanilla J., Coupelle P., Soares I. In the collection: Elsevier Science Publishing Company, Inc.// Journal of the european ceramic society, № 16, 2843-2853, ISSN: 0955-2219, eISSN: 1873-619X.

2. Bulatasov, E., Popov, V., \& Hanin, V. (2017). Determination of deformation characteristics of wood during cutting. University complex as a regional center for education, science and 


\begin{tabular}{|c|c|c|c|c|c|c|}
\hline \multirow{4}{*}{ Impact Factor: } & ISRA (India) & $=3.117$ & SIS (USA) & $=0.912$ & ICV (Poland) & $=6.630$ \\
\hline & ISI (Dubai, UAE & $=0.829$ & РИНЦ (Russia & $=0.156$ & PIF (India) & $=1.940$ \\
\hline & GIF (Australia) & $=0.564$ & ESJI (KZ) & $=8.716$ & IBI (India) & $=4.260$ \\
\hline & JIF & $=1.500$ & SJIF (Morocco & $=5.667$ & OAJI (USA) & $=0.350$ \\
\hline
\end{tabular}

Culture: materials of the All-Russian Scientific and Methodological Conference. (pp.15311535). Orenburg: OOO IPK "University".

3. Bucur, V. (2006). Acoustics of wood. 2nd edition. (p.111). Germany: Springer-Verlag Berlin Heidelberg.

4. Cooper, R. G., \& Wolf, D. (1968). Velocity profiles and pumping capacities for turbine type impellers. Canad J. Chem. Eng., 46, N 2, 1, 94 109.

5. Kobylkin, D. S., Antimonov, S. V., Korotkov, V. G., \& Ganin, E. V. (2008). Crushing under a vacuum in technology of receiving extruded kormosmesy and additives. Storage and processing of agricultural raw materials, No. 6 , 27-29.

6. Kishkilev, S. V., Korotkov, V. G., \& Popov, V. P. (2016). Development of mathematical model of cryocrushing of waste of agro-industrial complex. News of the Orenburg state agricultural university, No. 5, 66-67.

7. Antimonov, S. V., Solov, S. Y., \& Kishkilev, S. V. (2016). ldistost Coefficient as an indicator of quality of process of crushing of grain and the products of his processing which are previously cooled up to the negative temperatures. the University complex as the regional center of education, science and culture//Materials of the All-Russian scientific and methodical conference (with the international participation). (pp.1041-1043).

8. Timofeeva, D. V., Kishkilev, S. V., Popov, V. P., \& Martynov, N. N. (2016). A transformation Research structurally - mechanical properties and the chemical composition proteinaceous starch-fiber containing raw materials in the channel of an odnoshnekovy press extruder / //the University complex as the regional center of education, science and culture//Materials of the All-Russian scientific and methodical conference (with the international participation). (pp.1007-1014).

9. Korotkov, V. G., Kishkilev, S. V., Martynov, N. N., Martynova, D. V., \& Panov, E. I. (2015). Influence of shock freezing on quality and power consumption of process of crushing of grain raw materials and secondary material resources of food productions by various types of grinders. Technical science - from the theory to practice Publishing house: Association of research associates "Siberian academic book" (Novosibirsk). No. 52. (pp.193-202).

10. Antimonov, S. V., Kishkilev, S. V., Solov, S. Y., Korotkov, V.G., \& Popov, V. P. (2013). The Research of process of crushing of grain raw materials after shock freezing. Bakery products, No. 11, 60-62. 